\title{
Direct stimulation of bone mass by increased GH signalling in the osteoblasts of Socs2 ${ }^{-/-}$mice
}

\section{R Dobie, V E MacRae, C Huesa, R van't Hof', S F Ahmed ${ }^{2}$ and C Farquharson}

Division of Developmental Biology, The Roslin Institute and R(D)SVS, The University of Edinburgh, Easter Bush, Midlothian, Edinburgh EH25 9RG, Scotland, UK

${ }^{1}$ Institute of Ageing and Chronic Disease, University of Liverpool, Daulby Street, Liverpool L69 3GA, UK ${ }^{2}$ Developmental Endocrinology Research Group, School of Medicine, University of Glasgow, Yorkhill, Glasgow G3 8SJ, Scotland, UK
Correspondence should be addressed to R Dobie

Email

ross.dobie@roslin.ed.ac.uk

\begin{abstract}
The suppressor of cytokine signalling (Socs $2^{-\prime-}$ )-knockout mouse is characterised by an overgrowth phenotype due to enhanced GH signalling. The objective of this study was to define the Socs $2^{-1-}$ bone phenotype and determine whether GH promotes bone mass via IGF1-dependent mechanisms. Despite no elevation in systemic IGF1 levels, increased body weight in 4-week-old Socs2 ${ }^{-1-}$ mice following GH treatment was associated with increased cortical bone area (Ct.Ar) $(P<0.01)$. Furthermore, detailed bone analysis of male and female juvenile and adult Socs $2^{-1-}$ mice revealed an altered cortical and trabecular phenotype consistent with the known anabolic effects of $\mathrm{GH}$. Indeed, male Socs $2^{-1-}$ mice had increased Ct.Ar $(P<0.05)$ and thickness associated with increased strength. Despite this, there was no elevation in hepatic Igf1 expression, suggesting that the anabolic bone phenotype was the result of increased local GH action. Mechanistic studies showed that in osteoblasts and bone of Socs $2^{-1-}$ mice, STAT5 phosphorylation was significantly increased in response to GH. Conversely, overexpression of SOCS2 decreased GH-induced STAT5 signalling. Although an increase in Igf1 expression was observed in Socs $2^{-1-}$ osteoblasts following GH, it was not evident in vivo. Igf1 expression levels were not elevated in response to $\mathrm{GH}$ in 4-week-old mice and no alterations in expression was observed in bone samples of 6-week-old Socs $2^{-1-}$ mice. These studies emphasise the critical role of SOCS2 in controlling the local GH anabolic bone effects. We provide compelling evidence implicating SOCS2 in the regulation of $\mathrm{GH}$ osteoblast signalling and ultimately bone accrual, which maybe via mechanisms that are independent of IGF1 production in vivo.
\end{abstract}
Key Words
- GH/IGF1
- bone
- SOCS2
- osteoblast

Journal of Endocrinology

(2014) 223, 93-106

\section{Introduction}

Growth hormone $(\mathrm{GH})$ is a key regulator of postnatal skeletal development; however, its mode of action remains unclear (Slootweg 1993, Ohlsson et al. 1998). It is likely to involve both endocrine (systemic) actions via hepatic insulin-like growth factor 1 (IGF1) production and autocrine/paracrine (local) actions via the osteoblast
GH-receptor (GHR). In addition, local GH actions may be indirect (IGF1 dependent) or direct (IGF1 independent) (Isgaard et al. 1986, 1989, Le Roith et al. 2001).

The intimate relationship between GH and IGF1 makes it difficult to deduce the relative contributions of systemic and locally derived IGF1 to bone accrual. http://joe.endocrinology-journals.org DOI: $10.1530 / \mathrm{JOE}-14-0292$ (c) 2014 The authors Published by Bioscientifica Ltd Printed in Great Britain
This work is licensed under a Creative Commons Attribution 3.0 Unported License. 
While $\mathrm{Ghr}^{-/-}$mice have recognised changes in skeletal mass and architecture, these effects may be mediated through IGF1, as $\mathrm{Ghr}^{-/-}$mice have reduced systemic IGF1 levels (Sims et al. 2000, Sjogren et al. 2000). Global Igf1 $1^{-/-}$ and osteoblast-specific $I g f 1 r^{-/-}$mice also have altered bone architecture and diminished osteoid mineralisation (Bikle et al. 2001, Zhang et al. 2002).

Alterations in systemic IGF1, through the use of transgenic mouse models, offer an insight into the endocrine actions of IGF1 on bone turnover. Decreased systemic IGF1 levels results in an alteration in cortical geometry, with minimal alteration in trabecular bone (Sjogren et al. 2002, Yakar et al. 2002). Overexpression of Igf1 in hepatocytes results in supraphysiological IGF1 levels which is anabolic to cortical bone, and is able to substitute for skeletally derived IGF1 in global $I \& \mathrm{f}^{-/-}$ mice (Elis et al. 2010). Interpretation of some of these observations is complex as there is a 4.5 -fold increase in systemic GH levels in LID mice (Yakar et al. 2002). This may contribute to the bone phenotype, and mask the effects of low circulating IGF1 levels on bone mass in this and other mouse models (Yakar et al. 2009). Ideally, the in vivo study of the local effects of GH on cortical and trabecular bone formation would benefit from animal models, in which both circulating GH and IGF1 levels are normal. Studies with the GHR antagonist pegvisomant show that in a state of hepatic IGF1 insufficiency, GH protects the skeleton (Courtland et al. 2011). The targeted overexpression of $I g f 1$ to osteoblasts indicates that locally derived IGF1 is anabolic for bone (Zhao et al. 2000). Conversely, mice with a targeted ablation of $I g f 1$ in osteoblasts have a catabolic bone phenotype with no reports of decreased circulating IGF1 levels (Govoni et al. 2007).

The suppressor of cytokine signalling (SOCS) protein family consists of at least eight proteins, with SOCS1-3 recognised as inhibitors of GH/IGF1 signal. Basal levels of these proteins are low, but when stimulated by GH, expression levels rise quickly (SOCS1 and 3) or more gradually (SOCS2), forming a negative feedback loop (Tollet-Egnell et al. 1999). The absence of SOCS2 in mice results in an overgrowth phenotype (Metcalf et al. 2000). Firm evidence exists to show that SOCS2 acts on the GH pathway. The overgrowth phenotype is lost in Socs $2^{-1-}$; $G h r h r^{\text {lit/lit }}$, and diminished in Socs $2^{-/-}$; Stat $5 b^{-/-}$doubleknockout mice (Greenhalgh et al. 2005, Flores-Morales et al. 2006). The Socs $2^{-/-}$mouse is characterised by its overgrowth skeletal phenotype despite normal serum GH and IGF1 levels (Metcalf et al. 2000, Greenhalgh et al. 2002, MacRae et al. 2009). Aside from GH, SOCS2 has also been shown to be upregulated by oestrogen, and it is possible that GH controls bone mass, architecture, and strength in a gender-specific manner due to the influence of oestrogen on SOCS2 expression (Leung et al. 2003).

These data confirm the importance of the direct anabolic effects of $\mathrm{GH}$, and establish Socs $2^{-1-}$ mice as an informative model for studying the local effects of GH on osteoblast function and bone accretion. Whether GH promotes osteoblast functions via IGF1-dependent and/or independent mechanisms remains unresolved. This study therefore explored the mechanisms by which bone accretion is enhanced in male and female Socs $2^{-/-}$mice; and in doing so investigate the mechanisms of local GH control on osteoblast function.

\section{Material and methods}

\section{Mice}

The Socs $2^{-1-}$ mice used in this study were generated as described previously (MacRae et al. 2009). For genotyping, tail or ear biopsied DNA was analysed by PCR for SOCS2 WT or the neocassette (Socs $2^{-/-}$) using primers (Eurofins MWG Operon, London, UK) (Supplementary Table 1, see section on supplementary data given at the end of this article). All animal experiments were approved by Roslin Institute's Animal Users Committee, and the animals were maintained in accordance with Home Office (UK) guidelines for the care and use of laboratory animals.

\section{GH treatment}

From 14 days of age, male WT and Socs $2^{-/-}$mice received a s.c. injection of recombinant human (rh) GH (3 mg/kg), twice daily for 14 days. The control animals received sterile water. The mice were weighed each day before the first GH injection. Three hours after final GH-injection, the mice were killed. Blood was immediately extracted by cardiac puncture. The left femurs and livers were dissected, and the femurs had their epiphysis and marrow removed. Both livers and femurs were snap frozen in liquid nitrogen and stored at $-80^{\circ} \mathrm{C}$ for RNA extraction. Right femurs were dissected and stored in water at $-20^{\circ} \mathrm{C}$ for microcomputed tomography $(\mu \mathrm{CT})$ analysis.

In addition, male WT and Socs $2^{-/-}$mice at 24 days of age were given a single i.p. injection of rhGH $(3 \mathrm{mg} / \mathrm{kg})$ or sterile water for $15 \mathrm{~min}$, before being killed, and livers and tibiae extracted. The epiphysis was dissected from the tibiae, and marrow removed by centrifugation.

Published by Bioscientifica Ltd

Downloaded from Bioscientifica.com at $04 / 26 / 2023$ 09:58:56AM via free access 
The samples were snap frozen and stored at $-80{ }^{\circ} \mathrm{C}$ for protein extraction.

\section{Calcein labelling and tissue collection of adult and juvenile mice}

Male WT and Socs $2^{-/-}$mice received s.c. injections of $10 \mathrm{mg} / \mathrm{kg}$ calcein (Sigma) in sodium bicarbonate solution. In juvenile mice ( 6 weeks of age), injections were given 9 and 2 days before being killed. In adult mice (17 weeks of age), injections were given 16 and 2 days before being killed. At the point of sacrifice, 6-week-old male and female WT and Socs $2^{-/}$mice had their liver and right femur dissected and treated as previously described for RNA analysis. Left tibiae were also dissected and stored as previously described for $\mu \mathrm{CT}$. Right tibiae were dissected for tissue processing.

\section{IGF1 and IGFBP3 ELISA}

Serum samples were prepared, and total IGF1 levels were assessed by ELISA according to the manufacturer's instructions (Quantikine, R\&D Systems, Minneapolis, MN, USA). IGF1 assays included a step to dissociate the potentially interfering binding proteins from the ligand. IGF1 and IGFBP3 levels were also assessed in conditioned medium of osteoblast cultures (see below).

\section{Microcomputed tomography}

Tibiae were scanned using a $\mu \mathrm{CT}$ system (Skyscan 1172 X-Ray microtomograph, Bruker Corporation, Kontich, Belgium) to evaluate trabecular architecture and cortical bone geometry. For trabecular scanning, high-resolution scans with an isotropic voxel size of $5 \mu \mathrm{m}$ were acquired ( $60 \mathrm{kV}, 0.5 \mathrm{~mm}$ aluminium filter, $0.6^{\circ}$ rotation angle). The isotropic voxel size was changed to $10 \mu \mathrm{m}$ for cortical analysis. Two images were averaged at each rotation angle. The scans were reconstructed using NRecon software (Bruker). For analysis, a $1 \mathrm{~mm}$ section of the metaphysis was taken for the analysis of trabecular bone, using the base of the growth plate as a standard reference point. A $500 \mu \mathrm{m}$ section of the mid-shaft was taken for the analysis of cortical bone, using the articulation with the fibula as a standard reference point. CTAn software (Bruker) was used to analyse the appropriate parameters previously outlined (Bouxsein et al. 2010).

\section{Mechanical testing}

A Lloyd LRX5 materials testing machine (Lloyd Instruments, West Sussex, UK) fitted with a 500N load cell was used to determine bone stiffness and the point of failure of tibiae. The span was fixed at $10 \mathrm{~mm}$, and the cross-head was lowered at $1 \mathrm{~mm} / \mathrm{min}$. Data were recorded after every $0.2 \mathrm{~mm}$ change in deflection. Each bone was tested to failure, with failure points being identified as the point of maximum load from the load-extension curve. The maximum stiffness was defined as the maximum gradient of the rising portion of this curve. Both values were calculated from a polynomial curve fitted to the rising region of the load-extension curve in SigmaPlot (Huesa et al. 2011).

\section{Tissue processing and calcein labelling of tibia}

Tibiae fixed overnight in $4 \%$ paraformaldehyde (PFA) were embedded in methyl methacrylate. The sections $(5 \mu \mathrm{m})$ of the proximal tibia were cut and processed using standard procedures (Idris et al. 2009). The mineral apposition rate (MAR) was estimated at both the endosteal and periosteal surfaces at the mid-diaphysis of each tibia (Huesa et al. 2011).

\section{Osteoblast isolation and culture}

Osteoblasts were isolated from the calvaria of 3 to 5-dayold WT and Socs $2^{-/-}$mice (Zhu et al. 2011, Prideaux et al. 2012). The cells were pooled, centrifuged, and plated in aMEM containing 10\% foetal bovine serum, and $0.5 \%$ gentamicin (both Invitrogen). The cells were expanded in flasks in a humidified atmosphere of $95 \%$ air $/ 5 \% \mathrm{CO}_{2}$, and maintained at $37^{\circ} \mathrm{C}$ until $80-90 \%$ confluence. They were then plated at 10000 cells $/ \mathrm{cm}^{2}$ in multi-well plates. At confluence, the cells were incubated for $24 \mathrm{~h}$ in serum-free medium containing $0.1 \%$ BSA (Sigma). In keeping with previous studies, the cells were exposed to $500 \mathrm{ng} / \mathrm{ml} \mathrm{rhGH}$ or $50 \mathrm{ng} / \mathrm{ml} \mathrm{rhIGF} 1$ (both Bachem, Merseyside, UK) (DiGirolamo et al. 2007, Pass et al. 2012). Further modifications of this culture protocol are indicated in the results.

\section{RNA extraction and quantitative RT-PCR}

RNA was extracted from liver and cultured osteoblast samples (from above) using an RNeasy Mini Kit (Qiagen Ltd). Bone samples were homogenised using a mortar and pestle, and RNA was extracted using TRIzol reagent (Invitrogen). RNA content was measured by absorbance at $260 \mathrm{~nm}$, and quality by 260/280 ratios. RT was carried out as described previously (Farquharson et al. 1999). RT-qPCR was undertaken using a Stratagene Mx3000P

Published by Bioscientifica Ltd 
real-time qPCR machine with MxPro software (Stratagene, Santa Clara, CA, USA). Each cDNA sample was normalised to housekeeping genes Gapdh or Atp5b (Primer Design, Southampton, UK). The reactions were carried out with the genes of interest, primers for $I g f 1$ and $I g f b p 3$ (Invitrogen), as well as Socs1, Socs2 and Socs3 (Supplementary Table 1 ).

\section{Protein extraction and western blotting}

The cells and tissue were scraped and lysed in either RIPA buffer or Phospho-Safe lysis buffer (both Sigma), containing protease inhibitors (Roche). Protein content was determined using the DC protein assay (Bio-Rad Laboratories). The lysates were run on $3-8$ or $7 \%$ Tris-Acetate gels (for STAT, AKT and ERK1/2 proteins) or $10 \%$ Bis-Tris gels (for SOCS protein) (Supplementary Table 2, see section on supplementary data given at the end of this article). Following transfer, nitrocellulose films were blocked in 5\% BSA, and probed for $90 \mathrm{~min}$ (STAT, AKT and ERK1/2 proteins) or overnight (SOCS protein) with primary antibodies. The nitrocellulose was probed with peroxidase labelled secondary antibodies for a further $90 \mathrm{~min}$. ECL detection reagents were used to visualise bands on hyperfilm (Amersham, GE Healthcare, Bucks, UK). Where necessary, nitrocellulose was stripped using Restore Plus Stripping Buffer (Perbio Science, Northumberland, UK). Where appropriate, densitometry of western blotting was measured on three independent samples using Image J. Data are presented as phosphorylated protein normalised to total protein.

\section{Immunofluorescence of cultured cells}

Primary osteoblasts isolated from WT and Socs $2^{-1-}$ mice were grown on collagen-coated glass cover slips. Following exposure to rhGH $(500 \mathrm{ng} / \mathrm{ml})$ for $20 \mathrm{~min}$, the cells were fixed in 4\% PFA (15 min). Following a PBS wash, they were then permeabilised using methanol (5 min) at $-20^{\circ} \mathrm{C}$. After PBS washing, blocking buffer (5\% normal goat serum/0.3\% triton X-100) was added for $60 \mathrm{~min}$ and the cells were probed with pSTAT5 primary antibody overnight and subsequently a fluorochrome labelled secondary antibody for $60 \mathrm{~min}$ (Supplementary Table 2). Glass cover slips were then mounted onto slides using ProLong Gold antifade reagent with DAPI (Invitrogen) and cells were viewed by confocal microscopy.

\section{SOCS2 overexpression}

The pEF-FLAG-1/mSOCS2 (SOCS2 overexpression; SOCS2+) and pEF-FLAG-1 (control) plasmids were obtained from Prof. D Hilton. MC3T3-E1 osteoblast-like cells (ECACC, Salisbury, UK) were grown to $70 \%$ confluency in osteoblast maintenance medium (as mentioned earlier) and co-transfected with pEF-FLAG-1/mSOCS2 or pEF-FLAG-1 and PCDNA3.1(+) plasmids at a ratio of 5:1 using FuGene 6 (Roche) as previously described (Pass et al. 2012). Geneticin (Sigma)-resistant colonies were picked using cloning cylinders (Sigma); expanded, frozen and maintained at $-160^{\circ} \mathrm{C}$.

\section{Gene expression profiling}

Gene expression profiling for JAK/STAT target genes (84 target genes) was carried out using $\mathrm{RT}^{2}$ profiler PCR arrays (Qiagen). In accordance with previous studies, osteoblasts were challenged with rhGH $(500 \mathrm{ng} / \mathrm{ml})$ for $4 \mathrm{~h}$ to detect genes directly stimulated by STAT translocation to the nucleus, and not those downstream of secondary messengers (Greenhalgh et al. 2005, Govoni et al. 2006). RNA was extracted as described, and $1 \mu \mathrm{g}$ RNA was reverse transcribed with the $\mathrm{RT}^{2}$ profiler PCR array first-strand synthesis assay, followed by real-time PCR with $\mathrm{RT}^{2}$ realtime PCR master mix SYBR green.

\section{Statistical analyses}

Data were tested for normality and equal variance using SigmaPlot (v11.0) (Systat Software, Inc., London, UK). Direct comparison between two sets of data was made by Student's $t$-test. For multiple comparisons, data were analysed for statistical significance by 2-way ANOVA incorporating pairwise comparisons. Data are presented as mean \pm s.E.M. Values $P<0.05$ were considered significant.

\section{Results}

Increased growth and bone development in Socs $2^{-1-}$ mice

The increased growth rate of juvenile male Socs $2^{-/-}$ (103\%; $P<0.001)$, as measured by weight gain, was associated with increased periosteal expansion (Table 1 and Fig. 1A). Detailed analysis revealed increased periosteal MAR in the tibiae of male juvenile Socs $2^{-/-}$mice (44\%; $P<0.01$ ), but no change in endosteal MAR (Table 1

Published by Bioscientifica Ltd 
Table 1 Effects of SOCS2 on bone development in juvenile and adult male mice. Data are presented as mean \pm S.E.M. $n=3-5$ for growth data and $n=6$ for trabecular, cortical and biomechanical data

\begin{tabular}{|c|c|c|c|c|}
\hline & \multicolumn{2}{|c|}{6 weeks } & \multicolumn{2}{|c|}{17 weeks } \\
\hline & WT & Socs $2^{-1-}$ & WT & Socs $2^{-1-}$ \\
\hline \multicolumn{5}{|l|}{ Growth } \\
\hline Weight (g) & $21.3 \pm 0.29$ & $26.1 \pm 0.62^{\ddagger}$ & $32.9 \pm 1.68$ & $41.5 \pm 1.04^{\ddagger}$ \\
\hline Weight gain (g/day) & $0.29 \pm 0.034$ & $0.59 \pm 0.030^{\ddagger}$ & $0.02 \pm 0.030$ & $0.02 \pm 0.024$ \\
\hline Cortical endosteal MAR ( $\mu \mathrm{m} /$ day) & $3.3 \pm 0.15$ & $3.9 \pm 0.07$ & NA & NA \\
\hline Cortical periosteal MAR ( $\mu \mathrm{m} /$ day) & $3.6 \pm 0.30$ & $5.1 \pm 0.25^{\dagger}$ & NA & NA \\
\hline \multicolumn{5}{|l|}{ Trabecular } \\
\hline BV/TV (\%) & $15.4 \pm 0.69$ & $20.6 \pm 1.72^{\dagger}$ & $14.9 \pm 1.9$ & $19.6 \pm 1.07 *$ \\
\hline Tb.N (1/mm) & $3.4 \pm 0.01$ & $4.0 \pm 0.25$ & $3.0 \pm 0.41$ & $3.5 \pm 0.19$ \\
\hline Tb.Th $(\mathrm{mm})$ & $0.04 \pm 0.001$ & $0.05 \pm 0.002^{\dagger}$ & $0.05 \pm 0.002$ & $0.06 \pm 0.001^{\dagger}$ \\
\hline Tb.Sp (mm) & $0.17 \pm 0.01$ & $0.16 \pm 0.01$ & $0.2 \pm 0.01$ & $0.18 \pm 0.01$ \\
\hline SMI & $1.9 \pm 0.05$ & $1.7 \pm 0.08$ & $1.7 \pm 0.18$ & $1.5 \pm 0.05$ \\
\hline BMD $\left(\mathrm{g} / \mathrm{cm}^{3}\right)$ & $1.44 \pm 0.01$ & $1.46 \pm 0.03$ & $1.55 \pm 0.006$ & $1.45 \pm 0.06$ \\
\hline \multicolumn{5}{|l|}{ Cortical } \\
\hline Tt.Ar $\left(\mathrm{mm}^{2}\right)$ & $0.8 \pm 0.03$ & $1.0 \pm 0.03^{\dagger}$ & $0.9 \pm 0.06$ & $1.3 \pm 0.04^{\ddagger}$ \\
\hline Ct.Ar $\left(\mathrm{mm}^{2}\right)$ & $0.6 \pm 0.01$ & $0.7 \pm 0.03^{\ddagger}$ & $0.7 \pm 0.03$ & $0.9 \pm 0.02^{\ddagger}$ \\
\hline $\operatorname{Ma} \cdot \operatorname{Ar}\left(\mathrm{mm}^{2}\right)$ & $0.23 \pm 0.016$ & $0.25 \pm 0.015$ & $0.25 \pm 0.029$ & $0.41 \pm 0.018^{\ddagger}$ \\
\hline Ct.Th (mm) & $0.25 \pm 0.008$ & $0.28 \pm 0.011^{\dagger}$ & $0.27 \pm 0.003$ & $0.28 \pm 0.003$ \\
\hline$J\left(\mathrm{~mm}^{4}\right)$ & $0.10 \pm 0.003$ & $0.15 \pm 0.012 *$ & $0.13 \pm 0.016$ & $0.24 \pm 0.014^{\ddagger}$ \\
\hline $\operatorname{BMD}\left(\mathrm{g} / \mathrm{cm}^{3}\right)$ & $1.31 \pm 0.016$ & $1.29 \pm 0.04$ & $1.42 \pm 0.002$ & $1.35 \pm 0.008$ * \\
\hline \multicolumn{5}{|l|}{ Biomechanical } \\
\hline Failure load (N) & $8.0 \pm 0.39$ & $9.4 \pm 0.57$ & $11.1 \pm 2.46$ & $14.6 \pm 1.59 *$ \\
\hline Work to failure (mJ) & $2.6 \pm 0.23$ & $3.6 \pm 0.34^{*}$ & $3.3 \pm 0.71$ & $6.2 \pm 2.35^{*}$ \\
\hline Load to maximum stiffness $(\mathrm{N})$ & $4.4 \pm 0.33$ & $4.7 \pm 0.41$ & $6.2 \pm 1.62$ & $6.8 \pm 1.21$ \\
\hline Maximum stiffness $(\mathrm{N} / \mathrm{mm})$ & $18.6 \pm 1.52$ & $19.6 \pm 3.18$ & $28.4 \pm 8.57$ & $30.3 \pm 10.57$ \\
\hline
\end{tabular}

For trabecular data BV/TV, bone volume/tissue volume; Tb.N, trabecular number; Tb.Th, trabecular thickness; Tb.Sp, trabecular separation; SMI, structural model index. For cortical data Tt.Ar, total tissue area; Ct.Ar, cortical bone area; Ma.Ar, medullary area; Ct.Th, cortical thickness; J, polar moment of inertia. Significance from age-matched WT mice is denoted by ${ }^{\star} P<0.05,{ }^{\dagger} P<0.01,{ }^{\ddagger} P<0.001$.

and Fig. 1A). The overgrowth phenotype was still apparent in adult male Socs $2^{-/-}$mice $(26 \%$ heavier; $P<0.001)$; however, the growth rate was indistinguishable from agematched WT mice (Table 1). At this point, double-labelled calcein was rarely observed in the tibia; suggesting minimal bone growth.

\section{Altered bone architecture and geometry in Socs $2^{-/-}$mice}

The bone volume/tissue volume of the proximal tibia was increased in all Socs $2^{-/-}$mice (juvenile: male $34 \%$ $(P<0.01)$, female $31 \%(P<0.01)$; adult: male $32 \%(P<0.05)$ female $24 \%(P<0.05)$. This was most likely due to the increased trabecular thickness noted in the $\operatorname{Socs} 2^{-/-}$tibiae from juvenile (female 15\% $(P<0.01)$, male 14\% $(P<0.01)$ ) and adult mice (female $39 \%(P<0.001)$, male $12 \%$ $(P<0.01))$. The structural model index $(\mathrm{SMI})$ remained unchanged in the Socs $2^{-/-}$tibia (Tables 1 and 2). Juvenile and adult, male and female Socs $2^{-/-}$mice showed no alteration in trabecular BMD (Tables 1 and 2).

Analysis of cortical parameters revealed a $27 \%$ $(P<0.001)$ and $28 \%(P<0.001)$ increase in cortical bone area (Ct.Ar) of the tibiae from juvenile and adult male Socs $2^{-1-}$ mice respectively. Similar changes were not noted in the equivalent Socs $2^{-/-}$female mice (Tables 1 and 2). Grouping both ages together did reveal a genotype effect $(P<0.05)$. Consistent with increased Ct.Ar, total tissue area (Tt.Ar) was significantly greater in all Socs $2^{-/-}$ tibia $(P<0.05)$ (Tables 1 and 2$)$. Increases in marrow space (Ma.Ar) were, however, far less marked, with only juvenile female $(P<0.001)$ and adult male $(P<0.001)$ Socs $2^{-/-}$ tibiae showing increased Ma.Ar. Analysis of male Socs $2^{-/-}$ tibiae, compared with WT, revealed a significant increase in cortical thickness (Ct.Th) $(P<0.01)$. Age-defined analysis revealed that this increase was limited to juvenile Socs $2^{-/-}$tibiae $(P<0.01)$. Ct.Th was unchanged in female Socs $2^{-/-}$tibiae (Tables 1 and 2). Polar moment of inertia was increased in the Socs $2^{-/-}$tibiae of juvenile (female $37 \%(P<0.05)$, male 51\% $(P<0.05))$ and adult mice (female $24 \%(P<0.05)$, male $82 \%(P<0.001)$ ) (Tables 1 and 2). Cortical BMD in juvenile Socs $2^{-/-}$and WT mice was similar; however, BMD was significantly decreased in adult male $(P<0.05)$ and female $(P<0.01)$ Socs $2^{-/-}$ mice (Tables 1 and 2).

Published by Bioscientifica Ltd 
A
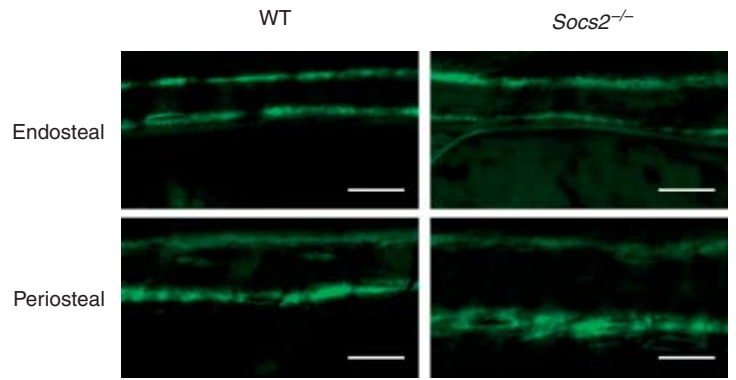

B
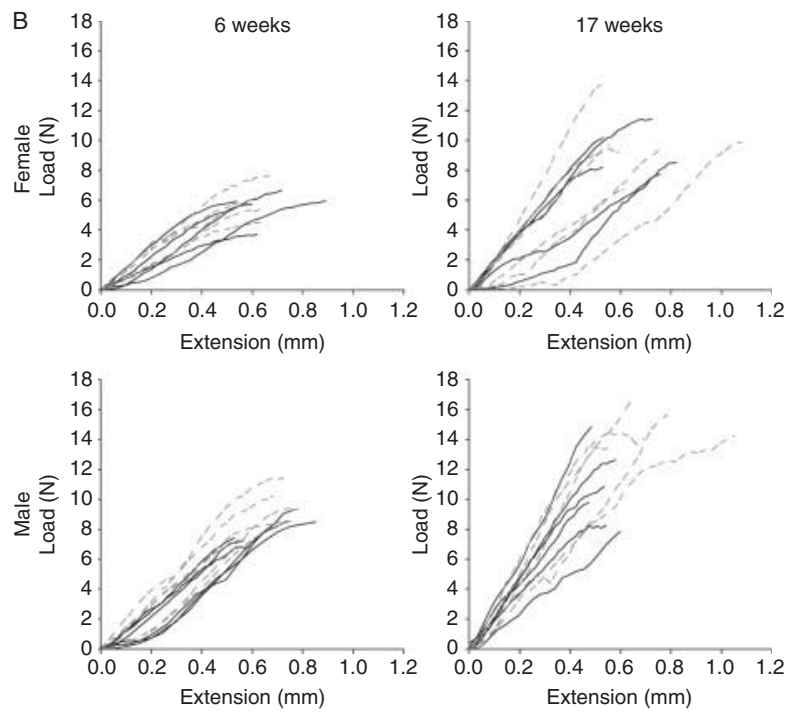

Figure 1

Socs $2^{-1-}$ cortical bone phenotype. (A) Images of periosteal and endosteal cortical bone apposition rate in tibia from juvenile 6-week-old male WT and Socs $2^{-1-}$ mice. Scale bar $=25 \mu \mathrm{m}$. (B) Load vs extension curves to point of failure of tibia from juvenile 6-week-old and adult 17-week-old, male and female WT (black) and Socs $2^{-1-}$ (grey hatched) mice.

\section{Increased strength of male Socs $2^{-/-}$tibiae}

Failure load, work to failure, load to maximum stiffness and maximum stiffness were unaltered in female Socs $2^{-/-}$ mice (Fig. 1B and Table 2). In contrast, tibiae from juvenile male Socs $2^{-/-}$mice showed a $41 \%$ increase in work to failure $(P<0.05)$. In adult mice, failure load $(32 \%, P<0.05)$ and work to failure $(90 \%, P<0.05)$ were both increased (Fig. 1B and Table 1). Load to maximum stiffness, and maximum stiffness of tibiae from male Socs $2^{-/-}$mice were not altered at either age (Table 1).

\section{SOCS2 regulates bone growth responses to $\mathrm{GH}$, independent of elevated systemic IGF1 levels}

Comparison of juvenile WT and Socs $2^{-/-}$mice revealed that despite the overgrowth phenotype of male $(23 \%$;
$P<0.001)$ and female $(18 \% ; P<0.01)$ Socs $2^{-/-}$mice (Tables 1 and 2), transcript levels of hepatic Igf1 were normal (Fig. 2A). Interestingly, there was a 2.2-fold increase in $I g f b p 3$ transcript levels in the livers of male Socs $2^{-/-}$mice $(P<0.05)$ (Fig. $\left.2 \mathrm{~A}\right)$.

To further assess the importance of systemic IGF1 in mediating the actions of $\mathrm{GH}$ on bone development in Socs $2^{-/-}$mice, male WT and Socs $2^{-/-}$mice were administered GH (Fig. 2B). Male Socs $2^{-/-}$mice treated with $\mathrm{GH}$ showed increased growth following 8 days treatment $(P<0.05)$ (Fig. $2 \mathrm{~B})$. WT mice showed no growth response at any time-point studied (Fig. 2B). Increased body weight in Socs $2^{-1-}$ mice was associated with an anabolic bone phenotype, characterised by increased Ct.Ar $(20 \%, P<0.01)$ and polar moment of inertia $(43 \%$, $P<0.05$ ) (Table 3 ). No differences were observed in WT bone (Table 3). Liver samples extracted at day 24 (representing a stage of $\mathrm{GH}$-induced growth promotion in Socs $2^{-/-}$mice) revealed elevated pSTAT5 levels in the livers of WT $(P<0.05)$ and Socs $2^{-/-}(P<0.001)$ mice following $15 \mathrm{~min} \mathrm{GH}$ treatment. The levels of pSTAT5 were much higher in the liver of Socs $2^{-/-}$mice (Fig. 2C). Despite increased STAT5 activation, increased growth and an anabolic bone phenotype (Fig. 2B, C and Table 3), GH treatment of Socs $2^{-/-}$mice did not increase hepatic Igf1 expression or systemic IGF1 levels at day 27 (Fig. 2D and E). Systemic IGF1 levels in GH-treated Socs $2^{-/-}$mice remained similar to those observed for control and GH-treated WT mice (Fig. 2E). Taken together, these results emphasise that the overgrowth phenotype noted in $\operatorname{Socs} 2^{-1-}$ mice is a result of a non-systemic IGF1mediated effects of local GH action.

\section{GH upregulates SOCS2 expression by osteoblasts}

In WT osteoblasts, GH increased Socs2, but not Socs1 and Socs3, mRNA expression after $24 \mathrm{~h}$ treatment $(P<0.001)$ (Fig. 3A). This was confirmed and extended by western blotting analysis following 24 and $48 \mathrm{~h} \mathrm{GH}$ treatment (Fig. 3B). IGF1 had no effects on SOCS1, SOCS2 and SOCS3 transcript or protein expression levels in WT cells (Fig. 3A and B). These data confirm SOCS2 as the primary SOCS protein regulating GH signalling in osteoblasts.

\section{SOCS2 negatively regulates GH-STAT intracellular signalling in osteoblasts and bone}

In WT osteoblasts, STAT3 was not activated (pSTAT) in response to $\mathrm{GH}$, whereas pSTAT1 was only observed

Published by Bioscientifica Ltd 
Table 2 Effects of SOCS2 on bone development in juvenile and adult female mice. Data are presented as mean \pm s.E.M. $(n=6)$

\begin{tabular}{|c|c|c|c|c|}
\hline & \multicolumn{2}{|c|}{6 weeks } & \multicolumn{2}{|c|}{17 weeks } \\
\hline & WT & Socs $2^{-1-}$ & WT & Socs $2^{-1-}$ \\
\hline \multicolumn{5}{|l|}{ Growth } \\
\hline Weight (g) & $16.3 \pm 0.62$ & $19.3 \pm 0.4^{+}$ & $26.2 \pm 0.91$ & $31.3 \pm 0.99^{\dagger}$ \\
\hline Weight gain (g/day) & $0.14 \pm 0.04$ & $0.21 \pm 0.04$ & $0.06 \pm 0.037$ & $0.02 \pm 0.05$ \\
\hline \multicolumn{5}{|l|}{ Trabecular } \\
\hline BV/TV (\%) & $9.7 \pm 0.25$ & $12.7 \pm 0.88^{\dagger}$ & $8.0 \pm 0.38$ & $9.9 \pm 0.52^{*}$ \\
\hline Tb.N (1/mm) & $2.4 \pm 0.09$ & $2.7 \pm 0.13 *$ & $1.6 \pm 0.10$ & $1.4 \pm 0.09$ \\
\hline Tb.Th (mm) & $0.04 \pm 0.001$ & $0.05 \pm 0.002^{\dagger}$ & $0.05 \pm 0.002$ & $0.07 \pm 0.001^{\ddagger}$ \\
\hline Tb.Sp (mm) & $0.22 \pm 0.01$ & $0.23 \pm 0.01$ & $0.28 \pm 0.01$ & $0.33 \pm 0.03 *$ \\
\hline SMI & $2.0 \pm 0.04$ & $2.0 \pm 0.05$ & $2.4 \pm 0.28$ & $2.3 \pm 0.10$ \\
\hline BMD $\left(\mathrm{g} / \mathrm{cm}^{3}\right)$ & $1.48 \pm 0.006$ & $1.47 \pm 0.01$ & $1.56 \pm 0.01$ & $1.57 \pm 0.01$ \\
\hline \multicolumn{5}{|l|}{ Cortical } \\
\hline Tt.Ar $\left(\mathrm{mm}^{2}\right)$ & $0.6 \pm 0.02$ & $0.7 \pm 0.01^{\dagger}$ & $0.7 \pm 0.02$ & $0.8 \pm 0.04 *$ \\
\hline Ct.Ar $\left(\mathrm{mm}^{2}\right)$ & $0.4 \pm 0.01$ & $0.5 \pm 0.01$ & $0.6 \pm 0.004$ & $0.6 \pm 0.02$ \\
\hline $\operatorname{Ma} . \operatorname{Ar}\left(\mathrm{mm}^{2}\right)$ & $0.19 \pm 0.008$ & $0.26 \pm 0.008^{\ddagger}$ & $0.16 \pm 0.008$ & $0.12 \pm 0.039$ \\
\hline Ct.Th (mm) & $0.21 \pm 0.005$ & $0.20 \pm 0.002$ & $0.26 \pm 0.009$ & $0.27 \pm 0.007$ \\
\hline $\mathrm{J}\left(\mathrm{mm}^{4}\right)$ & $0.05 \pm 0.003$ & $0.07 \pm 0.003 *$ & $0.08 \pm 0.007$ & $0.09 \pm 0.007 *$ \\
\hline BMD $\left(\mathrm{g} / \mathrm{cm}^{3}\right)$ & $1.34 \pm 0.007$ & $1.32 \pm 0.006$ & $1.44 \pm 0.005$ & $1.41 \pm 0.006^{\dagger}$ \\
\hline \multicolumn{5}{|l|}{ Biomechanical } \\
\hline Failure load (N) & $5.6 \pm 0.51$ & $5.7 \pm 0.45$ & $9.3 \pm 0.54$ & $10.0 \pm 0.90$ \\
\hline Work to failure (mJ) & $2.4 \pm 0.31$ & $2.0 \pm 0.22$ & $3.0 \pm 0.27$ & $3.0 \pm 0.26$ \\
\hline Load to maximum stiffness $(\mathrm{N})$ & $2.7 \pm 0.35$ & $2.1 \pm 0.27$ & $5.5 \pm 0.8$ & $5.7 \pm 0.5$ \\
\hline Maximum stiffness (N/mm) & $11.1 \pm 1.32$ & $12.5 \pm 0.95$ & $18.2 \pm 1.47$ & $22.7 \pm 3.42$ \\
\hline
\end{tabular}

For trabecular data BV/TV, bone volume/tissue volume; Tb.N, trabecular number; Tb.Th, trabecular thickness; Tb.Sp, trabecular separation; SMI, structural model index. For cortical data Tt.Ar, total tissue area; Ct.Ar, cortical bone area; Ma.Ar, medullary area; Ct.Th, cortical thickness; J, polar moment of inertia. Significance from age-matched WT mice is denoted by ${ }^{\star} P<0.05,{ }^{\dagger} P<0.01,{ }^{\ddagger} P<0.001$.

following 15 min of GH exposure. In contrast, pSTAT5 was observed at all-time points (15-120 min). Phosphorylation decreased with prolonged $\mathrm{GH}$ treatment. In Socs $2^{-/-}$ osteoblasts, the phosphorylation status of STAT1, STAT3 and STAT5 was both increased and prolonged by GH compared with WT (Fig. 3C). This was further confirmed by immunofluorescence where the stimulation of pSTAT5 by $\mathrm{GH}$ in both the cytoplasm and nucleus was much higher in Socs $2^{-/-}$osteoblasts (Fig. 3D). Increased pSTAT5 levels were also observed in $\operatorname{Socs} 2^{-/-}$bone samples following $15 \mathrm{~min} \mathrm{GH}$ treatment $(P<0.01)$ (Fig. 3G). The increase in pSTAT5 levels in bone from WT mice following GH treatment was far less, and did not reach significance from control bones (Fig. 3G). Comparable activation of ERK1/2 was observed in WT and Socs $2^{-/-}$osteoblasts following $\mathrm{GH}$ treatment, whereas AKT activation was not observed (Fig. 4A). GH did not stimulate AKT or ERK1/2 activation in bone samples from WT or Socs $2^{-/-}$mice following $15 \mathrm{~min}$ (Fig. 4C).

IGF1 did not phosphorylate STAT3 or STAT5, and the phosphorylation of AKT and ERK1/2 in response to IGF1 treatment was similar in WT and Socs $2^{-/-}$osteoblasts (Fig. 4A and B). These data confirm the negative role of SOCS2 on $\mathrm{GH}$-induced STAT signalling in osteoblasts and bone.

\section{Osteoblast SOCS2 overexpression inhibits GH-STAT intracellular signalling}

To fully appreciate the inhibitory role of SOCS2 on GH-STAT5 signalling, the effects of SOCS2 overexpression in MC3T3 osteoblast-like cells were investigated (Fig. 3E and F). In comparison with control osteoblasts, STAT5 phosphorylation in response to GH (15-120 min) was less in SOCS2 overexpressing cells (Fig. 3E). These results were confirmed by immunofluorescence (Fig. 3F).

\section{Little evidence for local IGF1 regulation of increased bone mass in Socs2 ${ }^{-1-}$ mice}

GH caused a small but significant increase in Igf1 (1.32fold, $P<0.01)$ and Igfbp3 (1.53-fold, $P<0.001)$ expression in WT osteoblasts, whereas in $\operatorname{Socs} 2^{-/-}$osteoblasts the increase in both $I g f 1(2.39$-fold, $P<0.001)$ and $I g f 1 b p 3$ (2.83-fold, $P<0.001)$ expression was of a slightly greater magnitude (Fig. 5A). To further identify whether Socs $2^{-/-}$ osteoblasts had a greater responsiveness to GH, IGF1 and IGFBP3 protein levels were measured in the conditioned medium of cultured osteoblasts. In Socs $2^{-1-}$, the increase in IGF1 and IGFBP3 protein level following GH treatment, although significant, was extremely small (1.14-fold

Published by Bioscientifica Ltd 
A
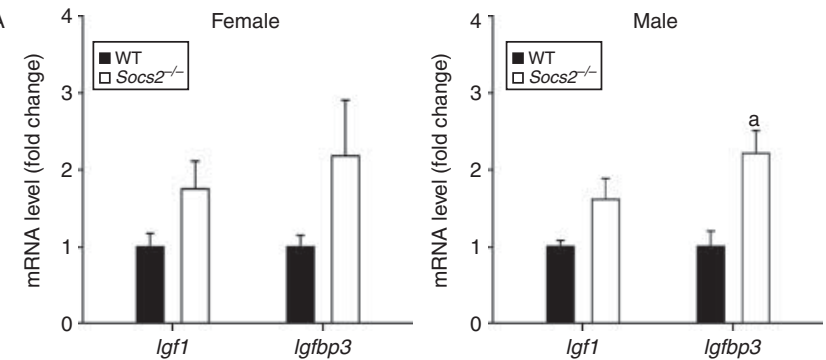

C

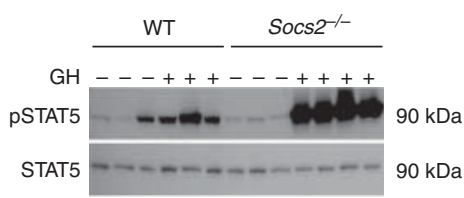

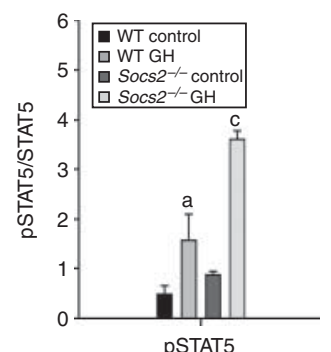

pSTAT5
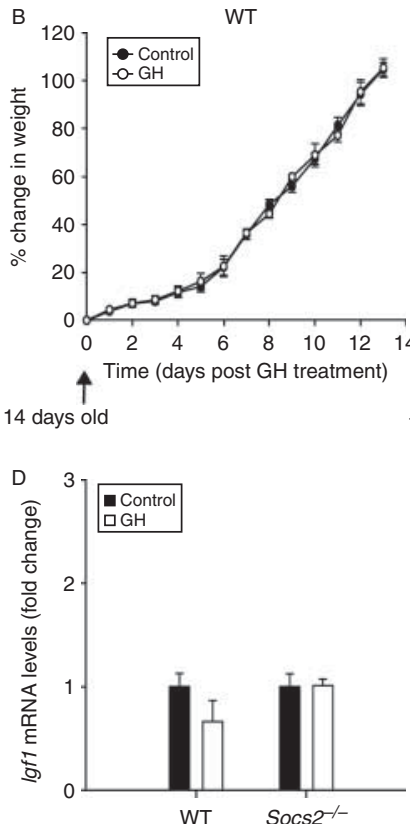
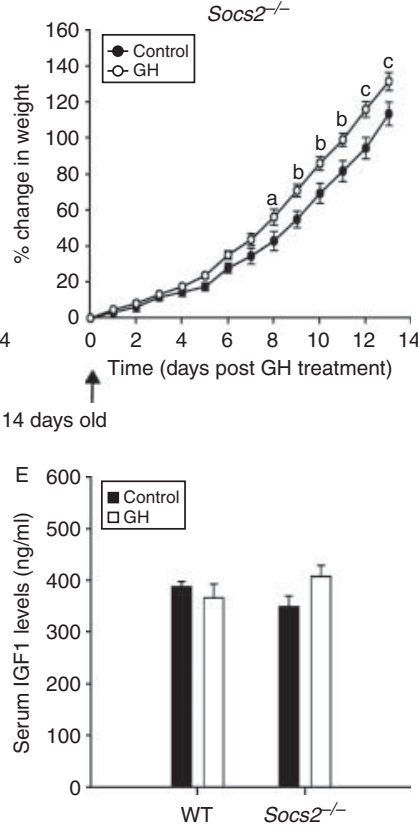

Figure 2

SOCS2 regulation of systemic IGF1. (A) Transcript analysis of Igf1 and Igfbp3 in liver samples of 6-week-old male and female WT and Socs $2^{-1-}$ mice. Data represented relative to sex-matched WT as mean \pm S.E.M. $(n=5)$. Significance from WT samples denoted by ${ }^{a} P<0.05$. (B) Graphs showing WT and Socs $2^{-1-}$ weight gain in response to twice daily $\mathrm{GH}(3 \mathrm{mg} / \mathrm{kg})$ from 14 to 27 days of age. Data presented as mean \pm S.E.M. $(n \geq 5)$. Significance from age-matched WT denoted by ${ }^{a} P<0.05,{ }^{b} P<0.01,{ }^{c} P<0.001$. (C) Western blotting analysis of phosphorylated (P-) STAT5 in 24-day-old WT $(-\mathrm{GH}(n=3) ;+\mathrm{GH}(n=3))$ and Socs2 ${ }^{-1-}(-\mathrm{GH}(n=3) ;+\mathrm{GH}(n=4))$

$(P<0.001)$ and 1.20 -fold $(P<0.001)$ respectively $)$. No significant changes in IGF1 and IGFBP3 protein levels were noted in WT osteoblasts (Fig. 5B). No increase in either $I g f 1$ or $I g f b p 3$ transcript levels was observed in tibia of WT and Socs $2^{-/-}$mice administered GH (Fig. 5C).

To directly address the higher bone mass noted in the $S o c s 2^{-/-}$mice, Igf1 and Igf $1 b p 3$ mRNA expression was quantified in femurs from mice previously analysed by $\mu \mathrm{CT}$ (Tables 1 and 2 ). The transcript levels of liver samples following $15 \mathrm{~min} \mathrm{GH}(3 \mathrm{mg} / \mathrm{kg}$ ) treatment. Band intensities were quantified by densitometry and analysed for significance, as depicted in the graphs. Data presented as mean \pm S.E.M. $(n \geq 3)$. Significance denoted by ${ }^{a} P<0.05,{ }^{C} P<0.001$. (D) Transcript analysis of Igf1 in liver samples from 27-day-old WT and Socs $2^{-1-}$ mice following 14 days twice daily GH (3 $\mathrm{mg} / \mathrm{kg}$ ) treatment. Data presented relative to untreated samples as mean \pm S.E.M. $(n=5)$. (E) Protein analysis by ELISA of IGF1 levels in serum extracted from 27-day-old WT and Socs $2^{-1-}$ mice following 14 days twice daily $\mathrm{GH}(3 \mathrm{mg} / \mathrm{kg})$ treatment.

Igf1 and Igfbp3 in Socs $2^{-/-}$and WT bones remained similar (Fig. 5D).

\section{Identification of osteoblast genes downstream of the JAK/STAT pathway stimulated by $\mathrm{GH}$}

In WT osteoblasts, the expression profiling revealed a significant induction of seven genes following $4 \mathrm{~h} \mathrm{GH}$ treatment (Sh2b2, Bcl2l1, Fr2, Fcgr1, Gata3, Gbp1 and

Table 3 Effects of SOCS2 on cortical bone development in male mice following 2 weeks rhGH $(3 \mathrm{mg} / \mathrm{kg})$ treatment. Data are presented as mean \pm s.E.M. $(n \geq 4)$

\begin{tabular}{|c|c|c|c|c|}
\hline & \multicolumn{2}{|c|}{ WT } & \multicolumn{2}{|c|}{ Socs2 ${ }^{-1-}$} \\
\hline & Control & $\mathrm{GH}$ & Control & $\mathrm{GH}$ \\
\hline Tt.Ar $\left(\mathrm{mm}^{2}\right)$ & $1.33 \pm 0.051$ & $1.30 \pm 0.070$ & $1.27 \pm 0.050$ & $1.45 \pm 0.070$ \\
\hline Ct.Ar $\left(\mathrm{mm}^{2}\right)$ & $0.45 \pm 0.023$ & $0.43 \pm 0.023$ & $0.41 \pm 0.009$ & $0.49 \pm 0.017^{\dagger}$ \\
\hline $\operatorname{Ma} \cdot \operatorname{Ar}\left(\mathrm{mm}^{2}\right)$ & $0.88 \pm 0.032$ & $0.87 \pm 0.048$ & $0.86 \pm 0.050$ & $0.96 \pm 0.061$ \\
\hline Ct.Th $(\mathrm{mm})$ & $0.12 \pm 0.003$ & $0.12 \pm 0.003$ & $0.12 \pm 0.004$ & $0.13 \pm 0.004$ \\
\hline $\mathrm{J}\left(\mathrm{mm}^{4}\right)$ & $0.17 \pm .0 .018$ & $0.15 \pm 0.017$ & $0.14 \pm 0.007$ & $0.20 \pm 0.015 *$ \\
\hline
\end{tabular}

For cortical data Tt.Ar, total tissue area; Ct.Ar, cortical bone area; Ma.Ar, medullary area; Ct.Th, cortical thickness; J, polar moment of inertia. Significance from genotype-matched control group is denoted by ${ }^{\prime} P<0.05,{ }^{\dagger} P<0.01$.

http://joe.endocrinology-journals.org
DOI: $10.1530 / J O E-14-0292$
(C) 2014 The authors Printed in Great Britain
Published by Bioscientifica Ltd 


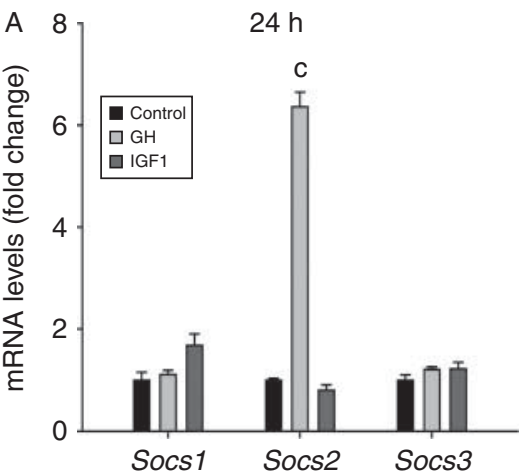

C
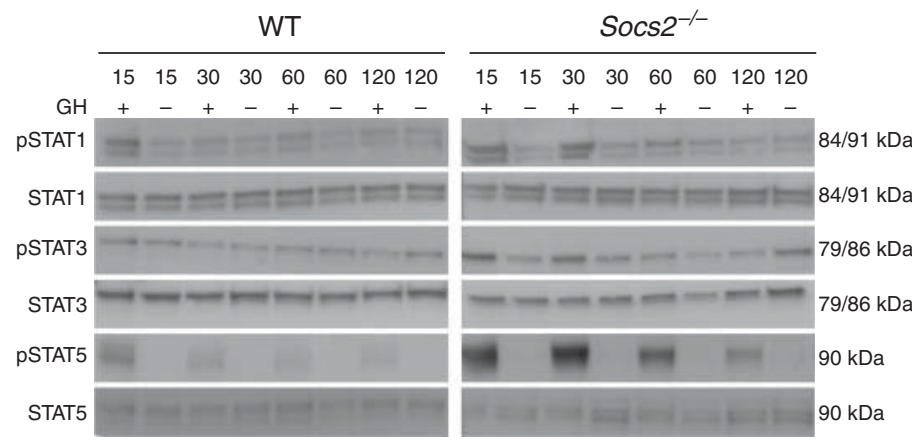

E
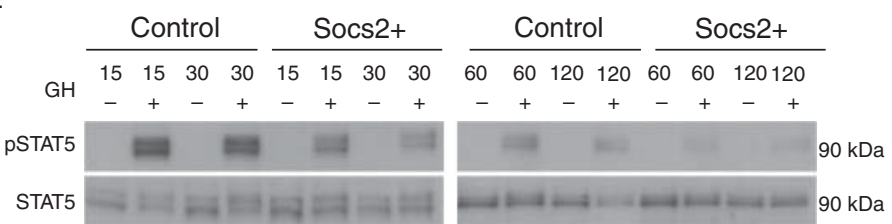

G

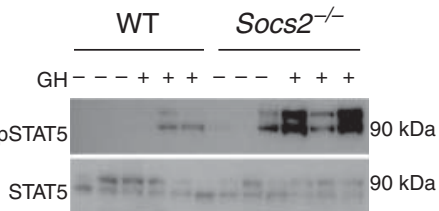

B

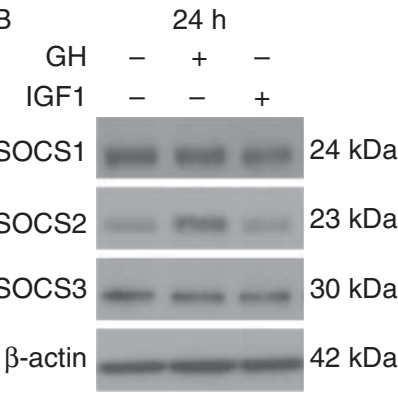

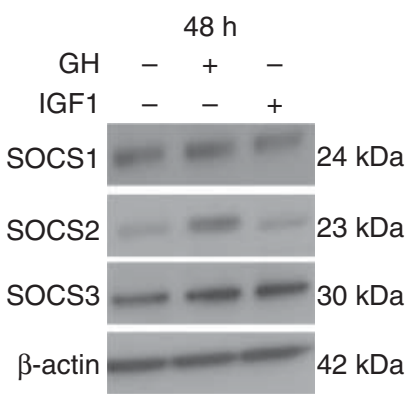

D

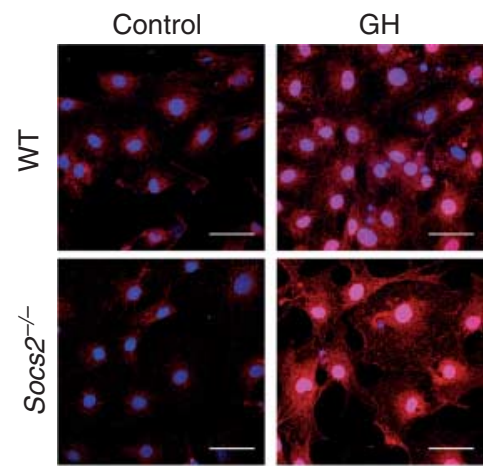

$\mathrm{F}$

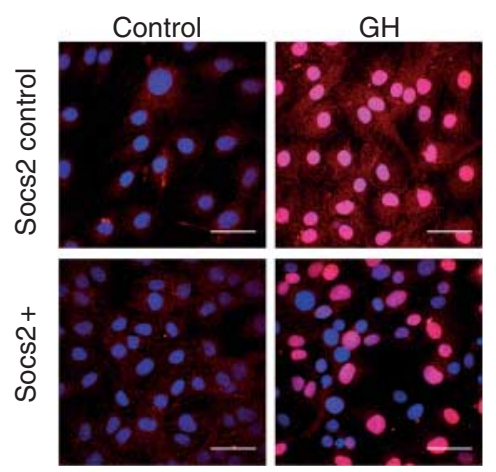

\section{Figure 3}

SOCS2 regulation of GH-induced STAT signalling in osteoblasts and bone. (A) Transcript analysis of Socs1, Socs2 and Socs 3 in WT osteoblasts following $24 \mathrm{~h} \mathrm{GH}(500 \mathrm{ng} / \mathrm{ml})$ or IGF1 $(50 \mathrm{ng} / \mathrm{ml})$ challenge. Transcript data represented relative to untreated samples as means \pm S.E.M. Significance denoted by ${ }^{C} P<0.001$. (B) Western blotting analysis of SOCS1, SOCS2 and SOCS3 in WT osteoblasts following 24 and $48 \mathrm{~h} \mathrm{GH}(500 \mathrm{ng} / \mathrm{ml})$ or IGF1 $(50 \mathrm{ng} / \mathrm{ml})$ treatment. (C) Western blotting analysis of phosphorylated $(\mathrm{P}-)$ STAT1, STAT3, and STAT5 in WT and Socs2 $2^{-1-}$ osteoblasts challenged with $\mathrm{GH}(500 \mathrm{ng} / \mathrm{ml})$ for up to $120 \mathrm{~min}$. (D) Immunofluorescence detection of PSTAT5 in WT and Socs $2^{-1-}$ osteoblasts following $20 \mathrm{~min} \mathrm{GH}(500 \mathrm{ng} / \mathrm{ml})$

Socs2). Only two genes showed over a twofold increase (Fcgr1, 4.46-fold, $P<0.05$ and Socs2, 4.55-fold, $P<0.05$ ) (Supplementary Figure 1 and Table 3 , see section on supplementary data given at the end of this article). challenge. (E) Analysis of (P-), STAT5 in SOCS2 overexpressing MC3T3 osteoblast-like cells and negative control-transfected cells following challenge with $\mathrm{GH}(500 \mathrm{ng} / \mathrm{ml})$ for up to $120 \mathrm{~min}$. (F) Immunofluorescence detection of PSTAT5 in SOCS2 overexpressing MC3T3 cells following $20 \mathrm{~min}$ $\mathrm{GH}(500 \mathrm{ng} / \mathrm{ml})$ challenge. Scale bars for immunofluorescence represent $50 \mu \mathrm{m}$. Nucleus, blue; pSTAT5, pink. (G) Analysis of (P-) STAT5 in bone samples extracted from 24-day-old WT and Socs $2^{-1-}$ mice following $15 \mathrm{~min}$ $\mathrm{GH}(3 \mathrm{mg} / \mathrm{kg}$ ) treatment. Band intensities were quantified by densitometry and analysed for significance, as depicted in the graphs. Data presented as mean \pm S.E.M. $(n=3)$. Significance denoted by ${ }^{b} P<0.01$.

GH-treated Socs $2^{-/-}$osteoblasts showed a significant increase in one gene $(C d k n 1 a)$ and a significant decrease in two genes (Sla2 and Stat4), with Stat4 showing a greater than twofold change $(-6.1$-fold, $P<0.05)$. In GH-treated 
A

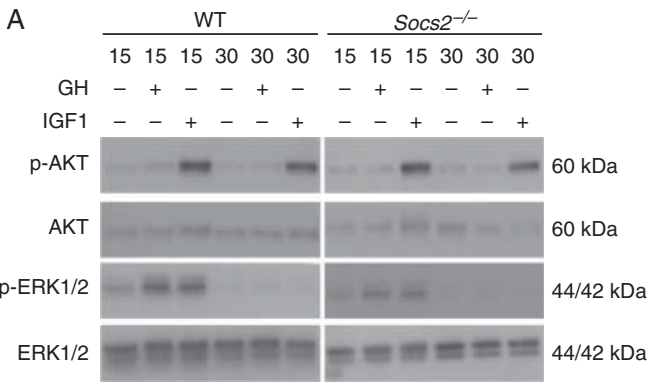

C

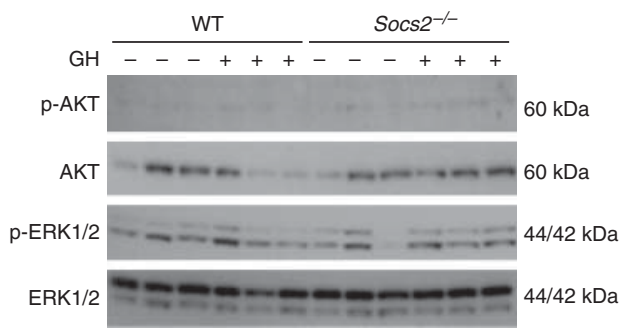

B
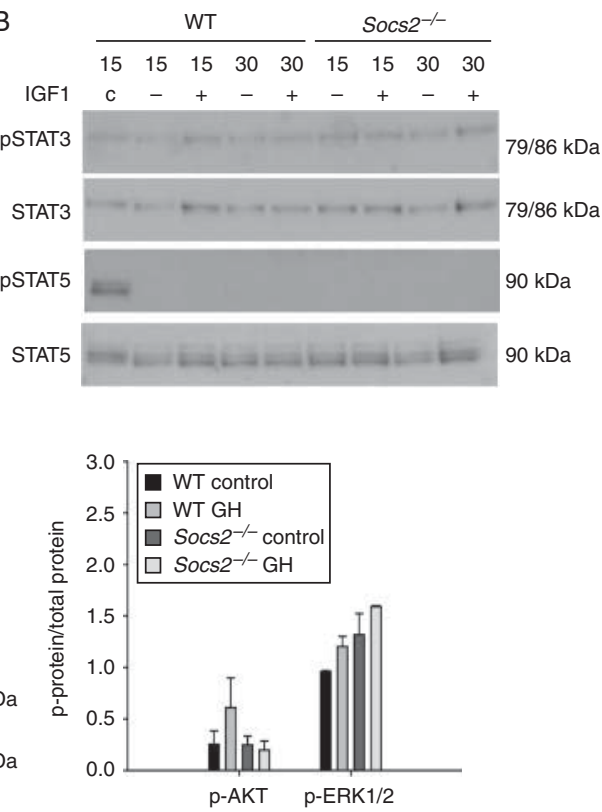

\section{Figure 4}

SOCS2 regulation of GH or IGF1-induced AKT and ERK1/2 signalling. (A) Western blotting analysis of phosphorylated (P-) AKT and (P-) ERK1/2 in WT and Socs $2^{-1-}$ osteoblasts challenged with GH $(500 \mathrm{ng} / \mathrm{ml})$ or IGF1 $(50 \mathrm{ng} / \mathrm{ml})$ for up to $30 \mathrm{~min}$. (B) Analysis of phosphorylated (P-) STAT3 and STAT5 in WT and Socs ${ }^{-1-}$ osteoblasts challenged with IGF1 $(50 \mathrm{ng} / \mathrm{ml})$ for

Socs $2^{-/-}$osteoblasts, Fcgr1 increased by 3.7-fold, but the difference did not reach significance $(P<0.076)$ (Supplementary Figure 1 and Table 3).

\section{Discussion}

The overgrowth phenotype observed in $\operatorname{Socs} 2^{-/-}$mice exhibits several features of deregulated GH signalling, including collagen accumulation in the dermis, and the decreased production of major urinary proteins (Metcalf et al. 2000, Greenhalgh et al. 2005). Furthermore, Socs $2^{-/-}$ mice are indistinguishable from WT littermates until 4-6 weeks, which coincides with the period of peak GH activity that occurs between postnatal days 20 and 40 (Wang et al. 2004). Circulating levels of GH and IGF1 in Socs $2^{-/-}$mice are normal; however, it is not known whether this is a consequence of impaired hepatic GH signalling and downstream gene transcription. Given that STAT5b is important for upregulating IGF1 expression, and also essential for the Socs $2^{-/-}$overgrowth phenotype, it is surprising that enhanced GH-induced hepatic STAT5 activation in Socs $2^{-/-}$mice did not result in raised serum IGF1 levels (Davey et al. 1999, 2001, Greenhalgh et al. 2002). Interestingly, several studies have also reported no increase in basal systemic IGF1 levels in Socs $2^{-/-}$mice. This suggests up to 30 min. C, GH-treated WT osteoblast acting as a positive control. (C) Analysis of phosphorylated (P-) AKT and ERK1/2 in bone samples extracted from WT and Socs $2^{-1-}$ mice following $15 \mathrm{~min} \mathrm{GH} \mathrm{(3} \mathrm{mg/kg)} \mathrm{treatment.} \mathrm{Band}$ intensities were quantified by densitometry and analysed for significance, as depicted in the graphs. Data presented as mean \pm S.E.M. $(n=3)$.

that the Socs $2^{-/-}$overgrowth phenotype is a result of increased endogenous GH signalling at a local level (Metcalf et al. 2000, Lorentzon et al. 2005, MacRae et al. 2009). In agreement with this, the present study highlights that the increased growth observed in juvenile, male and female Socs $2^{-1-}$ mice was not associated with increased hepatic Igf 1 expression, which is recognised as the main source of systemic IGF1 (Sjogren et al. 1999, Yakar et al. 1999). Other GH-regulated genes such as $I g f b p 3$ are preferentially expressed in the Socs $2^{-/-}$liver, and this was confirmed in male, but not in female mice (Rico-Bautista et al. 2005). The gender-specific effects of $\mathrm{GH}$ on $\mathrm{I} g \mathrm{f} b \mathrm{p} 3$ expression have been noted previously (Bielohuby et al. 2011). These observations underline the importance of local GH signalling and confirm the value of the Socs $2^{-/-}$mouse model in investigating the direct (IGF1 dependent or independent) anabolic effects of GH on growth and the skeleton.

In addition to their normal serum GH and IGF1 concentrations, Socs $2^{-/-}$mice also have normal carbohydrate metabolism (cf Alsko, Bp3ko, Lid and Igf1-null mice) (Rico-Bautista et al. 2005, Yakar et al. 2009). The anabolic structural bone changes in $G$ h-transgenic mice are similar to those observed in Socs $2^{-/-}$mice (Eckstein et al. 2004), but the $G h$-transgenic mice suffer from insulin resistance, which is not observed in the Socs $2^{-1-}$ model

Published by Bioscientifica Ltd 


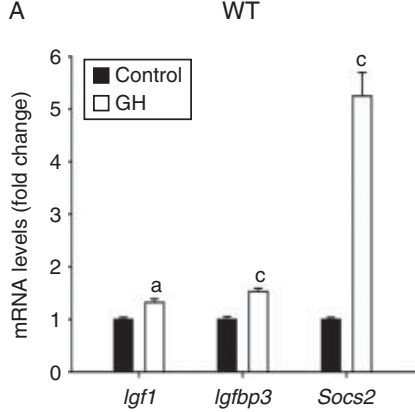

Socs2 $2^{-/}$

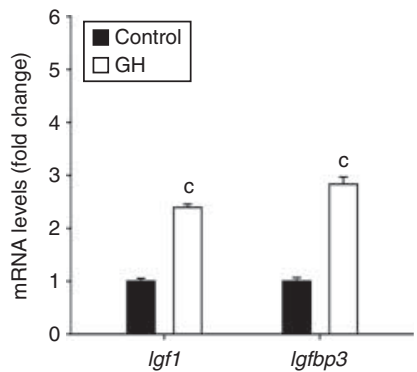

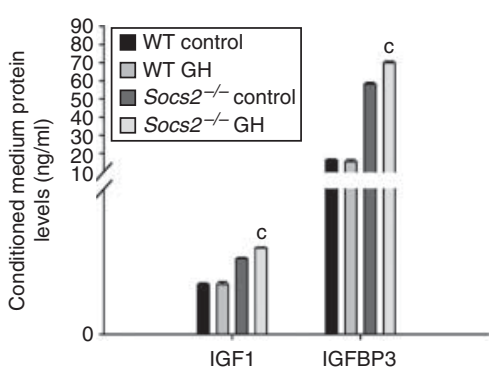
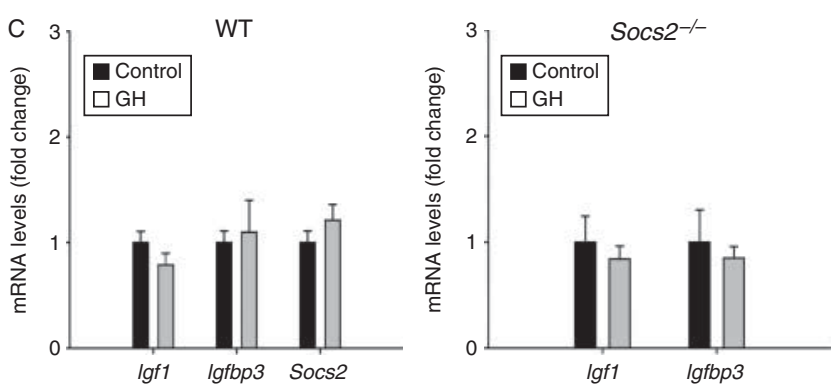
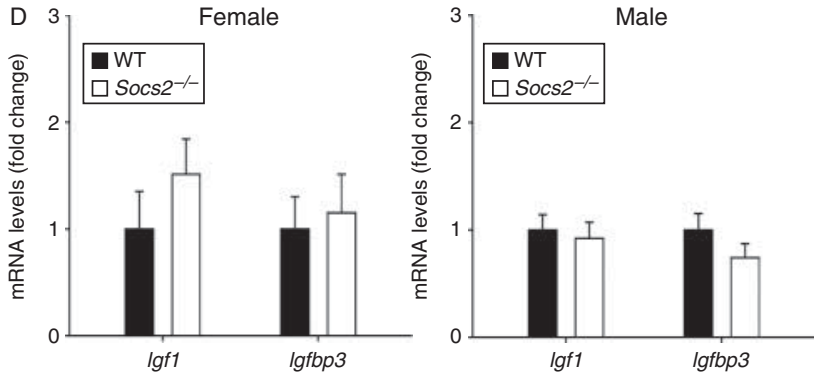

Figure 5

SOCS2 regulation of GH-induced IGF1 expression. (A) Transcript analysis of Igf1, Igfbp3 and Socs2 in WT and Socs $2^{-1-}$ osteoblasts following $48 \mathrm{~h} \mathrm{GH}$ $(500 \mathrm{ng} / \mathrm{ml})$ treatment. (B) Protein analysis of IGF1 and IGFBP3 from conditioned medium from WT and Socs $2^{-1-}$ osteoblasts following $48 \mathrm{~h} \mathrm{GH}$ (500 ng/ml) treatment. (C) Transcript analysis of Igf1 and Igfbp3 in bone samples extracted from 27-day-old male WT and Socs $2^{-1-}$ mice following 14 days twice daily GH (3 mg/kg) treatment. (D) Transcript analysis of $/ g f 1$ and lgfbp3 in bone samples extracted from 6-week-old male and female WT and Socs $2^{-1-}$ mice. All data represented as means \pm s.E.M. Significance from vehicle-treated samples denoted by ${ }^{\mathrm{a}} P<0.05,{ }^{\mathrm{c}} P<0.001$.
(Olsson et al. 2005). Thus, the Socs $2^{-/-}$mouse may represent an important model to study the pathways that promote bone accretion without leading to insulin resistance and altered carbohydrate metabolism.

The GH/IGF1 pathway is a critical regulator of osteoblast function, bone homeostasis and ultimately bone mass (Giustina et al. 2008). Global GH overexpression results in increased midshaft cross-sectional area; an observation that is more evident in males (Eckstein et al. 2004). Conversely, GH deficiency leads to decreased cortical periosteal circumference, cross-sectional area, and thickness; however, trabecular bone volume, number and thickness appear unchanged (Sims et al. 2000, Sjogren et al. 2000). Alterations in systemic IGF1 levels in these models make it difficult to delineate the relative contributions of $\mathrm{GH}$ and IGF1. Overexpression of GH in osteoblasts results in increased cortical area and strength, despite no increase in systemic IGF1 levels (Baker et al. 1992, Tseng et al. 1996). Conversely, overexpression of IGF1 in osteoblasts reveals an important role for local IGF1 in regulating trabecular architecture. There were minimal effects on cortical geometry, suggesting that all GH effects are not mediated through IGF1 (Zhao et al. 2000).
The present study found many similarities between the Socs $2^{-/-}$and GH excess model, including increased Tt.Ar. This is consistent with previous bone phenotype analysis of the Socs $2^{-/-}$mouse model, which focussed on 7-week-old female mice and the known anabolic effects of GH (MacRae et al. 2009). The increase in Tt.Ar is probably a result of increased periosteal bone formation. Juvenile male Socs $2^{-/-}$mice had increased periosteal MAR, which is a commonly used parameter for the characterisation of bone formation (Schilling et al. 1992). Similar to the GH excess models, male Socs $2^{-/-}$ mice displayed a more pronounced anabolic phenotype, with increased Ct.Ar and Ct.Th providing greater support to the cortex and consequently increasing bone strength (Davison et al. 2006). The gender-specific differences may be a consequence of the reported regulatory role of oestrogen on SOCS2 expression; however, this relationship merits further investigation (Leung et al. 2003). The increased trabecular bone parameters observed in juvenile Socs $2^{-1-}$ mice may be secondary to altered growth plate organisation, which has been previously reported in similar aged mice (Pass et al. 2012). Increased trabecular bone is however still evident in adult mice

Published by Bioscientifica Ltd 
when growth is negligible and the growth plate has been reduced to a thin layer of cells. This suggests that in adult mice, the trabecular bone phenotype is not secondary to alterations at the growth plate. Previous studies have produced varying results regarding the effects of SOCS2 on BMD, with some showing no effect, while others reporting a decrease (Lorentzon et al. 2005, MacRae et al. 2009). In this study, we report an agedependent decrease in cortical BMD in Socs $2^{-/-}$mice, with adults showing a decrease in BMD similar to that observed in the global GH excess model (Eckstein et al. 2004). Osteoblast-specific GH is anabolic to bone, and it has been proposed that this is at the expense of bone tissue integrity, such as increased cortical porosity which has been used as a predictor of BMD (Tseng et al. 1996, Wachter et al. 2002).

The activation of STAT1, STAT3 and STAT5 has been implicated in the regulation of gene transcription downstream of the GHR in various cell types; however in osteoblasts, the activation patterns remain unclear (Smit et al. 1996). In this study, we show that STAT1 and STAT5 are activated in response to GH in WT osteoblasts. In the absence of SOCS2, the GH-induced phosphorylation of osteoblast STAT1, STAT3 and STAT5, and the translocation of pSTAT5 to the osteoblast nucleus are increased compared with WT cells. The importance of SOCS2 in the regulation of GH-induced STAT5 activation in bone was further confirmed in vivo. The reliance of pSTAT5 for SOCS2 regulation of GH signalling has been clearly demonstrated in Socs $2^{-1-}$; Stat $5 b^{-/-}$double-knockout mice whose overgrowth phenotype is minimised (Greenhalgh et al. 2002). These data suggest that STAT 5 mediates $\mathrm{GH}$ anabolic actions on bone as reported for growth plate chondrocytes and linear bone growth (Teglund et al. 1998, Pass et al. 2012). Nevertheless, the bone phenotype of $\mathrm{Ghr}^{-/-}$mice is more severe than that of Stat $5 a b^{-1-}$ mice, suggesting additional GH actions on osteoblasts that are STAT5 independent (Sims et al. 2000). While GH-induced phosphorylation of ERK1/2 in osteoblasts, this was not observed in vivo. Likewise, no evidence for a SOCS2 regulatory role of this pathway was found, proposing that the high Socs $2^{-/-}$bone mass was not a result of increased GH-initiated ERK1/2 pathway.

Although the precise mechanism(s) by which SOCS2 negatively regulates GH signalling is unclear, the increased GH-induced phosphorylation of STAT1, STAT3 and STAT5 reported in osteoblasts implies that the inhibitory actions of SOCS2 are not STAT5 specific (Pass et al. 2009, Ahmed \& Farquharson 2010). The observation that inhibition or deletion of SOCS2 does not modify GH-induced activation of the ERK1/2 and AKT pathways advocates that SOCS2 regulates STAT activation only. A role for SOCS1 and SOCS3 in negatively regulating the osteoblast STAT response to GH was not supported by our data and confirms our previous observations in growth plate chondrocytes (Pass et al. 2012).

The JAK/STAT pathway is required for GH-induced IGF1 production, and mice deficient in STAT5b show a decrease in serum IGF1 levels (Herrington et al. 2000, Sims et al. 2000). Therefore, in Socs $2^{-1-}$ osteoblasts and bone, the increased STAT phosphorylation in response to GH is likely to result in higher Igfl expression and thereby offer an explanation for the increased bone mass of Socs $2^{-/-}$ mice. Previous studies on cultured osteoblasts have reported that GH has either no effect or causes only a slight increase in Igf1 expression (Schmid et al. 1994, DiGirolamo et al. 2007). This study reports similar small effects on $I g f 1$ and $I g f b p 3$ expression by GH, which were only slightly enhanced in Socs $2^{-/-}$osteoblasts. This indicates that SOCS2 can limit GH's ability to stimulate osteoblast Igf1 gene expression. Interestingly, it was also noted that basal levels of IGF1 and IGFBP3 were elevated in the condition medium of Socs $2^{-/-}$osteoblasts. It is however unlikely that these effects are mediated via GH as osteoblasts were serum starved. Nevertheless, this observation warrants further investigation. Our in vitro data, obtained in a primary cell culture scenario, were however not confirmed in two separate in vivo models. GH administration to Socs $2^{-/-}$mice was anabolic to bone, but showed no increase in bone $I g f 1$ and $I g f b p 3$ expression. Similarly, Socs $2^{-/}$mice with an over growth phenotype, increased bone mass and strength had unchanged levels of bone $I g f 1$ and $I g f b p 3$. The attempts to identify alternative signalling pathways, downstream of STAT signalling that are both stimulated by GH and negatively controlled by SOCS2, were unrewarding. Further studies are required to identify the specific signalling pathways initiated by GH's direct effects on osteoblasts.

In conclusion, this study underscores the critical role of SOCS2 in controlling GH's anabolic effects on bone. It also provides compelling evidence to support the notion that GH can regulate osteoblast function and ultimately bone mass via local mechanisms, that in vivo are perhaps independent of IGF1 production.

\section{Supplementary data}

This is linked to the online version of the paper at http://dx.doi.org/10.1530/ JOE-14-0292.

Published by Bioscientifica Ltd 


\section{Declaration of interest}

The authors declare that there is no conflict of interest that could be perceived as prejudicing the impartiality of the research reported.

\section{Funding}

This project was funded by the Biotechnology and Biological Sciences Research Council (BBSRC) UK and Ipsen (UK) through a CASE studentship award (R D), and Institute Strategic Programme Grant Funding from the BBSRC ( $C F, V E M, C H)$, BBSRC Institute Career Path Fellowship funding from the BBSRC ( $V E M)$.

\section{Acknowledgements}

The authors thank Prof. Douglas Hilton (The Walter and Eliza Hall Institute for Medical Research, Parkville, Victoria, Australia) for supplying the SOCS2 overexpression and control plasmids and Miss Elaine Seawright for her contributions to the experiments. The authors also thank Darren Smith and Alex Robertson of the Small Animal Unit.

\section{References}

Ahmed SF \& Farquharson C 2010 The effect of GH and IGF1 on linear growth and skeletal development and their modulation by SOCS proteins. Journal of Endocrinology 206 249-259. (doi:10.1677/JOE10-0045)

Baker AR, Hollingshead PG, Pittsmeek S, Hansen S, Taylor R \& Stewart TA 1992 Osteoblast-specific expression of growth-hormone stimulates bone-growth in transgenic mice. Molecular and Cellular Biology 12 5541-5547.

Bielohuby M, Schaab M, Kummann M, Sawitzky M, Gebhardt R, Binder G, Frystyk J, Bjerre M, Hoeflich A, Kratzsch J et al. 2011 Serum IGF-I is not a reliable pharmacodynamic marker of exogenous growth hormone activity in mice. Endocrinology 152 4764-4776. (doi:10.1210/en. 2011-1432)

Bikle D, Majumdar S, Laib A, Powell-Braxton L, Rosen C, Beamer W, Nauman E, Leary C \& Halloran B 2001 The skeletal structure of insulin-like growth factor I-deficient mice. Journal of Bone and Mineral Research 16 2320-2329. (doi:10.1359/jbmr.2001.16.12.2320)

Bouxsein ML, Boyd SK, Christiansen BA, Guldberg RE, Jepsen KJ \& Muller R 2010 Guidelines for assessment of bone microstructure in rodents using micro-computed tomography. Journal of Bone and Mineral Research $\mathbf{2 5}$ 1468-1486. (doi:10.1002/jbmr.141)

Courtland HW, Sun H, Beth-On M, Wu YJ, Elis S, Rosen CJ \& Yakar S 2011 Growth hormone mediates pubertal skeletal development independent of hepatic IGF-1 production. Journal of Bone and Mineral Research 26 761-768. (doi:10.1002/jbmr.265)

Davey HW, McLachlan MJ, Wilkins RJ, Hilton DJ \& Adams TE 1999 STAT5b mediates the GH-induced expression of SOCS-2 and SOCS-3 mRNA in the liver. Molecular and Cellular Endocrinology 158 111-116. (doi:10.1016/S0303-7207(99)00175-6)

Davey HW, Xie T, McLachlan MJ, Wilkins RJ, Waxman DJ \& Grattan DR 2001 STAT5b is required for GH-induced liver Igf-I gene expression. Endocrinology 142 3836-3841. (doi:10.1210/endo.142.9.8400)

Davison KS, Siminoski K, Adachi JD, Hanley DA, Goltzman D, Hodsman AB, Josse R, Kaiser S, Olszynski WP, Papaioannou A et al. 2006 Bone strength: the whole is greater than the sum of its parts. Seminars in Arthritis and Rheumatism 36 22-31. (doi:10.1016/j.semarthrit.2006.04.002)

DiGirolamo DJ, Mukherjee A, Fulzele K, Gan YJ, Cao XM, Frank SJ \& Clemens TL 2007 Mode of growth hormone action in osteoblasts. Journal of Biological Chemistry 282 31666-31674. (doi:10.1074/jbc. M705219200)
Eckstein F, Weusten A, Schmidt C, Wehr U, Wanke R, Rambeck W, Wolf E \& Mohan S 2004 Longitudinal in vivo effects of growth hormone overexpression on bone in transgenic mice. Journal of Bone and Mineral Research 19 802-810. (doi:10.1359/jbmr.040308)

Elis S, Courtland HW, Wu YJ, Rosen CJ, Sun H, Jepsen KJ, Majeska RJ \& Yakar S 2010 Elevated serum levels of IGF-1 are sufficient to establish normal body size and skeletal properties even in the absence of tissue IGF-1. Journal of Bone and Mineral Research 25 1257-1266. (doi:10.1002/ jbmr.20)

Farquharson C, Lester D, Seawright E, Jefferies D \& Houston B 1999 Microtubules are potential regulators of growth-plate chondrocyte differentiation and hypertrophy. Bone 25 405-412. (doi:10.1016/ S8756-3282(99)00187-8)

Flores-Morales A, Greenhalgh CJ, Norstedt G \& Rico-Bautista E 2006 Negative regulation of growth hormone receptor signaling. Molecular Endocrinology 20 241-253. (doi:10.1210/me.2005-0170)

Giustina A, Mazziotti G \& Canalis E 2008 Growth hormone, insulin-like growth factors, and the skeleton. Endocrine Reviews 29 535-559. (doi:10.1210/er.2007-0036)

Govoni KE, Lee SK, Chadwick RB, Yu HR, Kasukawa Y, Baylink DJ \& Mohan S 2006 Whole genome microarray analysis of growth hormoneinduced gene expression in bone: T-box3, a novel transcription factor, regulates osteoblast proliferation. American Journal of Physiology. Endocrinology and Metabolism 291 E128-E136. (doi:10.1152/ajpendo. $00592.2005)$

Govoni KE, Wergedal JE, Florin L, Angel P, Baylink DJ \& Mohan S 2007 Conditional deletion of insulin-like growth factor-I in collagen type $1 \alpha$ 2-expressing cells results in postnatal lethality and a dramatic reduction in bone accretion. Endocrinology 148 5706-5715. (doi:10.1210/en. 2007-0608)

Greenhalgh CJ, Bertolino P, Asa SL, Metcalf D, Corbin JE, Adams TE, Davey HW, Nicola NA, Hilton DJ \& Alexander WS 2002 Growth enhancement in suppressor of cytokine signaling 2 (SOCS-2)deficient mice is dependent on signal transducer and activator of transcription 5b (STAT5b). Molecular Endocrinology 16 1394-1406. (doi:10.1210/mend.16.6.0845)

Greenhalgh CJ, Rico-Bautista E, Lorentzon M, Thaus AL, Morgan PO, Willson TA, Zervoudakis P, Metcalf D, Street I, Nicola NA et al. 2005 SOCS2 negatively regulates growth hormone action in vitro and in vivo. Journal of Clinical Investigation 115 397-406. (doi:10.1172/ JCI200522710)

Herrington J, Smit LS, Schwartz J \& Carter-Su C 2000 The role of STAT proteins in growth hormone signaling. Oncogene 19 2585-2597. (doi:10.1038/sj.onc.1203526)

Huesa C, Yadav MC, Finnila MA, Goodyear SR, Robins SP, Tanner KE, Aspden RM, Milian JL \& Farquharson C 2011 PHOSPHO1 is essential for mechanically competent mineralization and the avoidance of spontaneous fractures. Bone 48 1066-1074. (doi:10.1016/j.bone. 2011.01.010)

Idris AI, Sophocleous A, Landao-Bassonga E, Canals M, Milligan G, Baker D, van't Hof RJ \& Ralston SH 2009 Cannabinoid receptor type 1 protects against age-related osteoporosis by regulating osteoblast and adipocyte differentiation in marrow stromal cells. Cell Metabolism 10 139-147. (doi:10.1016/i.cmet.2009.07.006)

Isgaard J, Nilsson A, Lindahl A, Jansson JO \& Isaksson OG 1986 Effects of local administration of GH and IGF-1 on longitudinal bone growth in rats. American Journal of Physiology. Endocrinology and Metabolism 250 E367-E372.

Isgaard J, Nilsson A, Vikman K \& Isaksson OG 1989 Growth hormone regulates the level of insulin-like growth factor-I mRNA in rat skeletal muscle. Journal of Endocrinology 120 107-112. (doi:10.1677/ joe.0.1200107)

Le Roith D, Bondy C, Yakar S, Liu JL \& Butler A 2001 The somatomedin hypothesis: 2001. Endocrine Reviews 22 53-74. (doi:10.1210/edrv.22. 1.0419)

Published by Bioscientifica Ltd 
Leung KC, Doyle N, Ballesteros M, Sjogren K, Watts CK, Low TH, Leong GM, Ross RJ \& Ho KK 2003 Estrogen inhibits GH signaling by suppressing GH-induced JAK2 phosphorylation, an effect mediated by SOCS-2. PNAS 100 1016-1021. (doi:10.1073/pnas.0337600100)

Lorentzon M, Greenhalgh CJ, Mohan S, Alexander WS \& Ohlsson C 2005 Reduced bone mineral density in SOCS-2-deficient mice. Pediatric Research 57 223-226. (doi:10.1203/01.PDR.0000148735.21084.D3)

MacRae VE, Horvat S, Pells SC, Dale H, Collinson RS, Pitsillides AA, Ahmed SF \& Farquharson C 2009 Increased bone mass, altered trabecular architecture and modified growth plate organization in the growing skeleton of SOCS2 deficient mice. Journal of Cellular Physiology 218 276-284. (doi:10.1002/jcp.21593)

Metcalf D, Greenhalgh CJ, Viney E, Willson TA, Starr R, Nicola NA, Hilton DJ \& Alexander WS 2000 Gigantism in mice lacking suppressor of cytokine signalling-2. Nature $\mathbf{4 0 5}$ 1069-1073. (doi:10.1038/ 35016611)

Ohlsson C, Bengtsson BA, Isaksson OG, Andreassen TT \& Slootweg MC 1998 Growth hormone and bone. Endocrine Reviews 19 55-79. (doi:10.1210/edrv.19.1.0324)

Olsson B, Bohlooly Y, Fitzgerald SM, Frick F, Ljungberg A, Ahren B, Tornell J, Bergstrom G \& Oscarsson J 2005 Bovine growth hormone transgenic mice are resistant to diet-induced obesity but develop hyperphagia, dyslipidemia, and diabetes on a high-fat diet. Endocrinology 146 920-930. (doi:10.1210/en.2004-1232)

Pass C, MacRae VE, Ahmed SF \& Farquharson C 2009 Inflammatory cytokines and the GH/IGF-I axis: novel actions on bone growth. Cell Biochemistry and Function 27 119-127. (doi:10.1002/cbf.1551)

Pass C, MacRae VE, Huesa C, Ahmed SF \& Farquharson C 2012 SOCS2 is the critical regulator of $\mathrm{GH}$ action in murine growth plate chondrogenesis. Journal of Bone and Mineral Research 27 1055-1066. (doi:10.1002/jbmr. 1544)

Prideaux M, Loveridge N, Pitsillides AA \& Farquharson C 2012 Extracellular matrix mineralization promotes E11/gp38 glycoprotein expression and drives osteocytic differentiation. PLOS ONE 7 e36786. (doi:10.1371/ journal.pone.0036786)

Rico-Bautista E, Greenhalgh CJ, Tollet-Egnell P, Hilton DJ, Alexander WS, Norstedt G \& Flores-Morales A 2005 Suppressor of cytokine signaling-2 deficiency induces molecular and metabolic changes that partially overlap with growth hormone-dependent effects. Molecular Endocrinology 19 781-793. (doi:10.1210/me.2004-0040)

Schilling T, Mueller M, Minne HW \& Ziegler R 1992 Mineral apposition rate in rat cortical bone: physiologic differences in different sites of the same tibia. Journal of Bone and Mineral Research 7 S429-S432. (doi:10.1002/ jbmr.5650071412)

Schmid C, Schlapfer I, Peter M, Bonischnetzler M, Schwander J, Zapf J \& Froesch ER 1994 Growth-hormone and parathyroid-hormone stimulate Igfbp-3 in rat osteoblasts. American Journal of Physiology $\mathbf{2 6 7}$ E226-E233.

Sims NA, Clement-Lacroix P, Da PF, Bouali Y, Binart N, Moriggl R, Goffin V, Coschigano K, Gaillard-Kelly M, Kopchick J et al. 2000 Bone homeostasis in growth hormone receptor-null mice is restored by IGF-I but independent of Stat5. Journal of Clinical Investigation 106 1095-1103. (doi:10.1172/JCI10753)

Sjogren K, Liu JL, Blad K, Skrtic S, Vidal O, Wallenius V, LeRoith D, Tornell J, Isaksson OG, Jansson JO et al. 1999 Liver-derived insulin-like growth factor I (IGF-I) is the principal source of IGF-I in blood but is not required for postnatal body growth in mice. PNAS 96 7088-7092. (doi:10.1073/ pnas.96.12.7088)

Sjogren K, Bohlooly YM, Olsson B, Coschigano K, Tornell J, Mohan S, Isaksson OG, Baumann G, Kopchick J \& Ohlsson C 2000 Disproportional skeletal growth and markedly decreased bone mineral content in growth hormone receptor - /- mice. Biochemical and Biophysical Research Communications 267 603-608. (doi:10.1006/bbrc.1999.1986)

Sjogren K, Sheng M, Moverare S, Liu JL, Wallenius K, Tornell J, Isaksson O, Jansson JO, Mohan S \& Ohlsson C 2002 Effects of liver-derived insulinlike growth factor I on bone metabolism in mice 43. Journal of Bone and Mineral Research 17 1977-1987. (doi:10.1359/jbmr.2002.17.11.1977)

Slootweg MC 1993 Growth-hormone and bone. Hormone and Metabolic Research 25 335-343. (doi:10.1055/s-2007-1002115)

Smit LS, Meyer DJ, Billestrup N, Norstedt G, Schwartz J \& Carter-Su C 1996 The role of the growth hormone $(\mathrm{GH})$ receptor and JAK1 and JAK2 kinases in the activation of Stats 1, 3, and 5 by GH. Molecular Endocrinology 10 519-533. (doi:10.1210/mend.10.5.8732683)

Teglund S, Mckay C, Schuetz E, van Deursen JM, Stravopodis D, Wang DM, Brown M, Bodner S, Grosveld G \& Ihle JN 1998 Stat5a and Stat5b proteins have essential and nonessential, or redundant, roles in cytokine responses. Cell 93 841-850. (doi:10.1016/S0092-8674(00) 81444-0)

Tollet-Egnell P, Flores-Morales A, Stavreus-Evers A, Sahlin L \& Norstedt G 1999 Growth hormone regulation of SOCS-2, SOCS-3, and CIS messenger ribonucleic acid expression in the rat. Endocrinology 140 3693-3704. (doi:10.1210/endo.140.8.6878)

Tseng KF, Bonadio JF, Stewart TA, Baker AR \& Goldstein SA 1996 Local expression of human growth hormone in bone results in impaired mechanical integrity in the skeletal tissue of transgenic mice. Journal of Orthopaedic Research 14 598-604. (doi:10.1002/jor.1100140414)

Wachter NJ, Krischak GD, Mentzel M, Sarkar MR, Ebinger T, Kinzl L, Claes L \& Augat P 2002 Correlation of bone mineral density with strength and microstructural parameters of cortical bone in vitro. Bone 31 90-95. (doi:10.1016/S8756-3282(02)00779-2)

Wang J, Zhou J, Cheng CM, Kopchick JJ \& Bondy CA 2004 Evidence supporting dual, IGF-I-independent and IGF-I-dependent, roles for GH in promoting longitudinal bone growth. Journal of Endocrinology $\mathbf{1 8 0}$ 247-255. (doi:10.1677/joe.0.1800247)

Yakar S, Liu JL, Stannard B, Butler A, Accili D, Sauer B \& LeRoith D 1999 Normal growth and development in the absence of hepatic insulin-like growth factor I. PNAS 96 7324-7329. (doi:10.1073/pnas.96.13.7324)

Yakar S, Rosen CJ, Beamer WG, Ackert-Bicknell CL, Wu YP, Liu JL, Ooi GT, Setser J, Frystyk J, Boisclair YR et al. 2002 Circulating levels of IGF-1 directly regulate bone growth and density. Journal of Clinical Investigation 110 771-781. (doi:10.1172/JCI0215463)

Yakar S, Rosen CJ, Bouxsein ML, Sun H, Mejia W, Kawashima Y, Wu Y, Emerton K, Williams V, Jepsen K et al. 2009 Serum complexes of insulin-like growth factor- 1 modulate skeletal integrity and carbohydrate metabolism. FASEB Journal 23 709-719. (doi:10.1096/ fj.08-118976)

Zhang M, Xuan S, Bouxsein ML, von Stechow D, Akeno N, Faugere MC, Malluche H, Zhao G, Rosen CJ, Efstratiadis A et al. 2002 Osteoblast-specific knockout of the insulin-like growth factor (IGF) receptor gene reveals an essential role of IGF signaling in bone matrix mineralization. Journal of Biological Chemistry $27744005-44012$. (doi:10.1074/jbc.M208265200)

Zhao G, Monier-Faugere MC, Langub MC, Geng Z, Nakayama T, Pike JW, Chernausek SD, Rosen CJ, Donahue LR, Malluche HH et al. 2000 Targeted overexpression of insulin-like growth factor I to osteoblasts of transgenic mice: increased trabecular bone volume without increased osteoblast proliferation. Endocrinology 141 2674-2682.

Zhu DX, Mackenzie NCW, Millan JL, Farquharson C \& MacRae VE 2011 The appearance and modulation of osteocyte marker expression during calcification of vascular smooth muscle cells. PLOS ONE 6 e19595. (doi:10.1371/annotation/60addd69-bd2d-4ecf-8369-6a5a1 bf2cd04)

Received in final form 30 June 2014

Accepted 29 July 2014

Accepted Preprint published online 29 July 2014 http://joe.endocrinology-journals.org DOI: $10.1530 /$ JOE-14-0292 (c) 2014 The authors Printed in Great Britain
Published by Bioscientifica Ltd 